\title{
Corporate Social Responsibility, Internal Control and Enterprise Value-Based on the Chinese Stock Market
}

\author{
Xianjun Gao \\ Business School of Nanjing Normal University, Nanjing, China \\ Email: 1261835976@qq.com
}

How to cite this paper: Gao, X.J. (2019) Corporate Social Responsibility, Internal Control and Enterprise Value-Based on the Chinese Stock Market. Open Journal of Social Sciences, 7, 30-49.

https://doi.org/10.4236/jss.2019.77004

Received: May 29, 2019

Accepted: July 8, 2019

Published: July 11, 2019

Copyright $\odot 2019$ by author(s) and Scientific Research Publishing Inc. This work is licensed under the Creative Commons Attribution International License (CC BY 4.0).

http://creativecommons.org/licenses/by/4.0/

Open Access

\begin{abstract}
Taking China's A-share listed companies as the research sample, this paper studies the relationship between corporate social responsibility, internal control and enterprise value. The research results show that there is a positive correlation between the corporate social responsibility and the enterprise value. It shows corporate social responsibility behavior will enhance the enterprise value. At the same time, the behavior of corporate social responsibility also contributes to the improvement of enterprise internal control. Internal control has a partial intermediary role in the process of social responsibility affecting enterprise value. In that way, the corporate social responsibility can affect enterprise value by improving enterprise internal control. Further research shows that compared with the private enterprises, the internal control in the state-owned enterprises has a more significant partial mediating effect in the process of corporate social responsibility affecting enterprise value.
\end{abstract}

\section{Keywords}

Social Responsibility, Enterprise Value, Internal Control, Intermediary Utility

\section{Introduction}

As the issue of Corporate Social Responsibility (CSR) is more and more concerned, shareholders, investors and other stakeholders, are increasingly demanding that companies should not only be responsible for them, but also for the society. Investors will consider the company's moral issues when they are making investment decisions, and customers will pay attention to the social impact of the enterprise when they are making purchase decisions. Therefore, in 
order to meet the growing demand for corporate social responsibility, enterprises begin to disclose their corporate social responsibility reports and take corporate social responsibility as an important part of corporate strategy. However, there are still some controversies. Does corporate social responsibility increase or decrease shareholder wealth? Is it good for the long-term development of the enterprise?

In recent years, more and more enterprises began to establish internal control system, and take internal control system as an important means to prevent business risks and enhance enterprise value. At the same time, the Ministry of Finance issued the "Guidelines for the Application of Internal Control of Enterprises No. 4-Social Responsibility", requiring enterprises to combine corporate social responsibility and internal control. But what is the relationship between internal control and corporate social responsibility? What role does internal control play in the impact of corporate social responsibility on enterprise value? This is the focus of this paper.

In previous studies on social responsibility, corporate social responsibility, internal control and enterprise value are rarely combined. Therefore, this paper examines the relationship between corporate social responsibility and enterprise value, and the role that internal control plays in the relationship between social responsibility and enterprise value. This study not only provides a reference for shareholders and managers to understand the relationship between corporate social responsibility and enterprise value, and but also provides a basis for stakeholders to evaluate the role of internal control.

Based on the data of China's A-share listed companies from 2012 to 2017, this paper finds that corporate social responsibility can significantly affect the enterprise value, and internal control plays a partial intermediary role between corporate social responsibility and enterprise value. In addition, the intermediary effect of internal control is more obvious in state-owned enterprises.

The rest of the paper is structured as follows. Section 2 provides literature review and research hypotheses. Section 3 discusses the sample, variable measurements, and research design. Section 4 presents empirical results and discusses the findings. Section 5 concludes the study.

\section{Literature Review and Research Hypotheses}

\subsection{Literature Review}

\subsubsection{Corporate Social Responsibility and Corporate Value}

The research on the economic consequences of CSR has not reached a consistent conclusion since the 1970s. Supporters of social responsibility believe that corporate social responsibility will maximize the interests of all stakeholders and shareholders [1] [2] [3]. Companies with high social responsibility ratings show better growth in stock market-based indicators (such as risk-adjusted returns) and accounting-based indicators (such as ROA, business income growth rate) [4], and the conflict among stakeholders of the enterprise is lower [5]. Through 
social responsibility investment, enterprises can attract responsible consumers and obtain financing from investors with a sense of social responsibility [6], with lower corresponding financing cost [7]. In addition, the strength of this relationship is influenced by the enterprise life cycle [8]. Opponents of the corporate social responsibility believe that the fulfillment of social responsibility by enterprises serves the interests of management rather than shareholders [9]. Corporate Social responsibility behaviors will increase the operating cost of enterprises, weaken their competitiveness and ultimately reduce their value [10]. Besides, scholars have found that enterprises' social responsibility to customers and employees will reduce their financial performance [11]. Because of the existence of agency costs, shareholders will bear the risks and costs of corporate social responsibility, while the benefits will be enjoyed by the management. Therefore, corporate social responsibility is actually a kind of agency cost [12], and the behavior of corporate social responsibility is more like a "self-care tool" of the management, which will not bring the improvement of corporate value [13].

\subsubsection{Corporate Social Responsibility and Internal Control}

The interaction between corporate social responsibility and internal control has always been the focus of scholars. On the one hand, in order to ensure the fulfillment of corporate social responsibility, enterprises need to improve the corporate governance system [14]. Because a good corporate governance system will improve the fulfillment level of corporate social responsibility [15]. Besides, the internal control is the essence of corporate governance system [16]. Because a good internal control system can not only promote the regularization and standardization of corporate social responsibility performance, effectively solve the problem that corporate social responsibility performance relies on managers' personal preference [17], but also can promote the information disclosure and commitment of corporate social responsibility [18]. On the other hand, the undertaking of corporate social responsibility will improve the internal control environment and improve the internal control of enterprises [19]. Enterprises assume more social responsibilities to stakeholders, which will create a public image that complies with the law, openness and sustainability. Therefore, enterprises are bound to establish a set of perfect internal control system to maintain this image [20]. At the same time, enterprises with good social responsibility can provide higher quality financial reports [21] and face lower financial risks [22]. This means that it is easier for companies to achieve the basic goals of internal control and the higher the quality of internal control [23].

\subsubsection{Internal Control and Enterprise Value}

The economic consequences of internal control have gone beyond the scope proposed in the COSO report, which has a significant positive effect on the improvement of enterprise performance and value [24]. Internal control can improve an enterprise's agency cost [25], earnings quality [26], information transparency and value [27]. In addition, enterprises with high internal control quali- 
ty face lower tax burden [28], lower possibility of financial distress [29], lower risk of stock price decline, and have generally better business performance than companies with defects in internal control [30]. In addition, internal control also has an important impact on inhibiting the company's inefficient investment [31], the capital occupation of major shareholders [32], and the decisions of directors, CFO and other executives and corporate stakeholders [33].

With a review of the literature, it can be found that the current scholars focus on the relationship between social responsibility, enterprise value and internal control. However, there are relatively few studies on the interaction mechanism of the three factors combined. Therefore, based on the existing research, this paper further studies whether social responsibility can promote the improvement of enterprise value by improving the internal control of enterprises, that is, whether internal control has an intermediary role in the relationship between social responsibility and enterprise value. The study of this paper provides a reference for shareholders and other stakeholders to understand whether social responsibility improves enterprise value, and provides a basis for the objective evaluation of the internal control system.

\subsection{Research Hypotheses}

\subsubsection{The Hypothesis of the Relationship between Corporate Social Responsibility and the Enterprise Value}

There are three ways that corporate social responsibility affects the enterprise value. Firstly, corporate social responsibility can coordinate the relationship between enterprises and stakeholders. Enterprises are "a set of contracts" concluded by stakeholders [34], according to which resources stakeholders invest into enterprises. Corporate social responsibility is the essential embodiment of stakeholders' demands for contracts. Specifically, corporate social responsibility refers to the responsibility that an enterprise must assume to shareholders, creditors, suppliers, government, employees, customers, communities and other stakeholders and the environment in its production and operation activities [35]. Therefore, companies with good corporate social responsibility will maintain a positive relationship with stakeholders. So that conflicts between stakeholders and management will be alleviated [36], and the agency cost of enterprises will be reduced accordingly. Secondly, corporate social responsibility can be used as a signal transmission mechanism [37] to reduce the information asymmetry of enterprises [38]. For investors, due to the existence of information asymmetry, they cannot completely identify the quality of a company, which will eventually lead to adverse selection and other problems. However, corporate social responsibility activities will convey to investors that they are trustworthy, which will reduce agency costs between enterprises and investors, enhance investors' confidence to obtain more financing support. Finally, corporate social responsibility activities can improve corporate reputation [39]. Corporate social responsibility behavior involves all stakeholders, and corporate social responsibility activities will affect the evaluation of stakeholders on enterprises. The higher the corpo- 
rate social responsibility rating is, the higher the external evaluation will be [40]. In that way, a good reputation will be formed among stakeholders. This reputation will become an intangible resource owned by the enterprise, which can form its competitive advantage and ultimately increase its value.

In summary, corporate social responsibility can affect the value of enterprises through internal and external approaches. On the one hand, it can improve the operating efficiency of the enterprises by reducing their agency costs; on the other hand, it can strengthen their competitive advantages and increase their value. Therefore, based on the above analysis, the following research hypothesis is proposed.

Hypothesis 1 . The fulfillment of corporate social responsibility by an enterprise can enhance its value.

\subsubsection{The Hypothesis of the Relationship between Corporate Social Responsibility and Internal Control}

The relationship between corporate social responsibility and internal control is the focus of scholars. There are two ways for the influence of corporate social responsibility on internal control. First, corporate social responsibility helps to optimize the internal control environment. The control environment contains the factors such as the governance structure and enterprise culture, which is the foundation of internal control. Corporate social responsibility activities is a kind of moral behavior related form good corporate culture, and good corporate culture will promote the beneficial future transactions. Corporate social responsibility to the staff behavior can give employees a sense of security to enhance the enthusiasm of employees. It is beneficial to increase the enterprise's internal cooperation [41], and to improve the enterprise internal control environment [19]. It is also advantageous to the enterprise internal control construction in the end. Second, corporate social responsibility contributes to the realization of internal control objectives. Internal control of the basic goals includes providing reliable financial reporting and guard against the risk of enterprise. The existing research shows that fulfill the social responsibility of the company can provide more transparent and reliable financial reports [42]. This is because the government and the outside world attaches great importance to the social responsibility of corporate. This is a form of external supervision, therefore, enterprise managers are more likely to adhere to high standards of behavior. Honesty and morality motive is stronger, and the likelihood of false earnings reports would also be reduced [43]. At the same time, reputation effect produced by social responsibility behavior will form a protection mechanism. When an enterprise encounters a negative event, this mechanism will give the enterprise a larger buffer space to mitigate the impact of the negative event on the enterprise and reduce the severity of the risk.

In summary, the establishment of an effective internal control system requires the joint efforts of all stakeholders. The fulfillment of corporate social responsibility can enhance the cooperation within enterprises and improve the imple- 
mentation of internal control. Therefore, based on the above analysis, the following research hypothesis is proposed.

Hypothesis 2. Corporate social responsibility can improve the internal control of enterprises.

\subsubsection{The Hypothesis of the Relationship between Corporate Social Responsibility, Enterprise Value and Internal Control}

Through the above analysis shows that the corporate social responsibility behavior can shape a good corporate image. In order to maintain the image, with a higher moral standard of managers will be the establishment of the corresponding internal control system [20]. And in that way, enterprise operation and management will become transparent. The interests of all stakeholders can get better safeguard. Stakeholders will give companies more trust. Enterprise decreases in the agency cost of the enterprise and the management efficiency will be higher. In the end, it will promote the enterprise's value. In addition, the implementation of corporate social responsibility is the enterprise in the release to the world "their trustworthy" signal. At the same time, to show the sustainability and reliability of the signal, socially responsible companies will strengthen their internal control construction. The companies will take the internal control system as the guarantee of its corporate social responsibility sustainability and address the public's concerns about the integrity and credibility of enterprises' performance of social responsibilities [44].

Therefore, companies with a sense of corporate social responsibility have a strong incentive to ensure that their CSR behaviors are reliable. The higher the CSR rating, the easier it is for enterprises to establish an effective internal control system. More stakeholders will adhere to the basic standards of internal control. The operation of the enterprise will become more transparent, and the agency cost of the enterprise will be reduced, and the value of the enterprise will be increased. Therefore, based on the above analysis, the following research hypothesis is proposed.

Hypothesis 3. Enterprises fulfill corporate social responsibility can improve their value by improving their internal control. That is, internal control plays an intermediary role in the relationship between social responsibility and enterprise value.

The difference of property right nature of enterprises has always been an important topic for Chinese scholars. Due to the particularity of China's economic system, the coexistence of state-owned enterprises and private enterprises has always been the unique embodiment of China's economic system. State-owned enterprises face more supervision and pressure from government departments in their operations. Therefore, state-owned enterprises assume more social responsibilities and are more likely to assume corporate social responsibilities. At the same time, government departments have formulated relevant laws and regulations for state-owned enterprises to fulfill their corporate social responsibilities. While undertaking corporate social responsibilities, state-owned enterprises will 
inevitably establish corresponding internal control systems to meet the requirements of these laws and regulations. However, private enterprises face less external pressure to undertake corporate social responsibility, and their corporate social responsibility is mainly determined by the values of managers, so it is more arbitrary and unsustainable. Therefore, based on the different property rights, the following research hypothesis is proposed.

Hypothesis 4. It is more obvious that state-owned enterprises improve enterprise value by undertaking corporate social responsibility and perfecting internal control.

\section{Research Methodology}

\subsection{Sample and Variables}

In this paper, we select Chinese A-share companies listed on the Shanghai and Shenzhen Exchanges from 2012 to 2017 as the research objects. We excluded the following companies: 1) ST, PT (listed company under special treatment), 2) financial companies, and 3) those with incomplete data. In order to avoid the influence of extreme values on the empirical results, this paper conducted a reduction treatment on the main continuous variables at the level of $1 \%$ and $99 \%$. Finally, a total of 7572 study samples were obtained from 1262 companies. The social responsibility data in this paper are from HeXun

(http://www.hexun.com/), the internal control index is from DIB internal control database (http://www.ic-erm.com/), and all the financial data involved are from CSMAR database (http://www.gtarsc.com/Home). Before the analysis, relevant variables are standardized and Stata 12.0 is used for statistical analysis.

\subsubsection{Measurement}

1) The Enterprise Value Measurement. In this paper, economic added value (EVA) is used as a measure of enterprise value. Economic added value (EVA) refers to the income after deducting all the invested capital cost including equity and debt from the after-tax net operating profit. Its core is that capital investment has costs, because companies only create value for shareholders when their profits are higher than their capital costs (including equity costs and debt costs). The adoption of EVA as the measurement variable of enterprise value can overcome the disadvantages of the traditional evaluation system, such as ignoring the cost of equity capital and the short-term behavior of enterprises [45], to measure the actual value of enterprises more comprehensively.

2) CSR Measurement. Following prior studies [43], in this paper, the social responsibility score published by HeXun is used as the measurement index of corporate social responsibility. The social responsibility score released by HeXun is calculated based on the corporate social responsibility report published on the official website of the listed companies in Shanghai and Shenzhen (http://www.hexun.com/). The rating system examines the corporate social responsibility from five dimensions: shareholder responsibility, employee responsibility, supplier responsibility, customer and consumer rights and interests' re- 
sponsibility, environmental responsibility and social responsibility. The higher the CSR score, the better the CSR performance level.

3) Internal Control. In this paper, we used the DIB internal control information disclosure index to reflect the quality of internal control information disclosure. The data were obtained from the DIB internal control and risk management database (http://www.ic-erm.com/). DIB internal control index is a research result designed based on foreign internal control index and combined with China's institutional environment and the current situation of listed companies. The index range is 0 - 1000. This paper uses its self-admission logarithm to measure the quality of internal control. The larger the internal control index is, the more perfect the internal control system is.

\subsubsection{Control Variables}

Following prior studies [1] [18] [37], we used several control variables for the factors that have been shown to affect the dependent variables of enterprise value and internal control efficiency.

A summary of the variable definitions is shown in Table 1.

\subsection{Empirical Models}

Firstly, according to hypothesis 1, in order to test the relationship between corporate social responsibility and enterprise value, the following model is constructed in this paper. The significant CSR coefficient is one of the prerequisites for the existence of mediating effect

$$
\mathrm{EVA}_{i, t}=\alpha_{0}+\alpha_{1} \mathrm{CSR}_{i, t}+\alpha_{2} \text { Controls }_{i, t}+\varepsilon_{i, t}
$$

Secondly, according to hypothesis 2 , in order to test the relationship between corporate social responsibility and internal control, the following model is constructed in this paper. The significant CSR coefficient in model 2 is another prerequisite for the existence of mediating effect.

$$
\mathrm{IC}_{i, t}=\beta_{0}+\beta_{1} \mathrm{CSR}_{i, t}+\beta_{2} \text { Controls }_{i, t}+\varepsilon_{i, t}
$$

Thirdly, according to hypothesis 3, and using the method for testing the intermediate factors presented by Wen Zhonglin [46], we investigate whether internal controls play a mediating role in the relationship between CSR and the enterprise value. The following model is constructed in this paper. The significant IC coefficient in model 3 is another prerequisite for the existence of mediating effect. In addition, $\gamma_{1}$ in model 3 was compared with $\alpha_{1}$ in model 1 to verify whether internal control, as a mediating variable, plays a mediating role in the process of corporate social responsibility affecting enterprise value. If $\gamma_{1}$ in model 3 is not significant, there is no mediating effect. If $\gamma_{1}$ in model 3 is significant and decreased compared with the $\alpha_{1}$ coefficient in model 1, it indicates that there is a partial mediating effect of internal control, and hypothesis 3 is verified.

$$
\mathrm{EVA}_{i, t}=\gamma_{0}+\gamma_{1} \mathrm{CSR}_{i, t}+\gamma_{2} \mathrm{IC}_{i, t}+\gamma_{3} \operatorname{Controls}_{i, t}+\varepsilon_{i, t}
$$


Table 1. Summary of variable definitions.

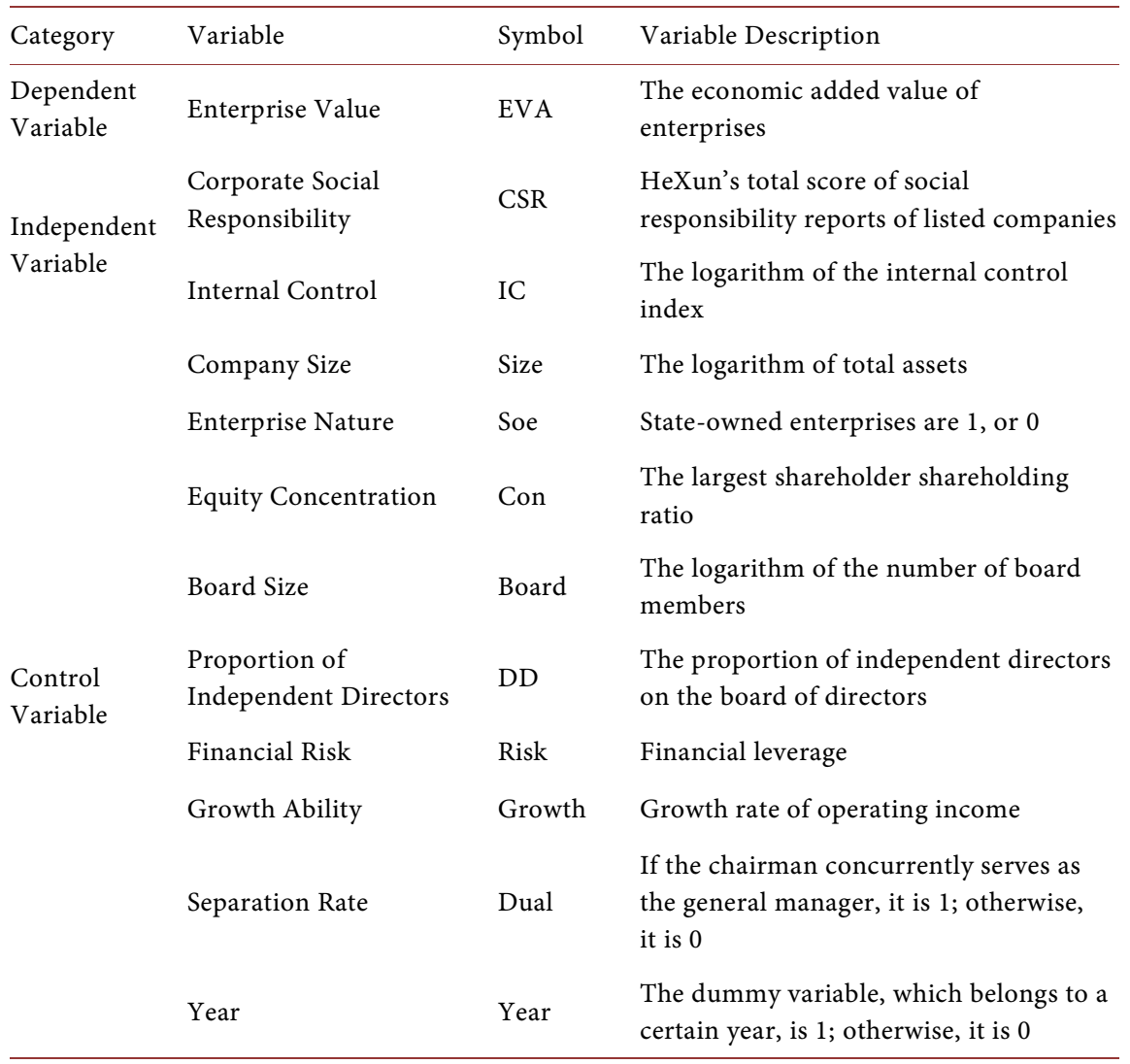

\section{Results and Discussion}

\subsection{Descriptive Statistics}

Table 2 shows descriptive summary of the variables. The average value of the economic added value (EVA) is 1.784 . The significant SD indicated that the EVA varied widely between different companies in China. And the SD of the EVA is 10.231. It shows that there are great differences in the value of the sample companies. The average CSR is 28.460 , indicating that the performance of social responsibility of China's listed companies is still at a low level on the whole. The SD of the CSR is 18.782, indicating that there is a big difference in the corporate social responsibility of the sample companies. In our firm dataset, the average firm has an IC score of 667.362 . For the company ownership, $49.76 \%$ are state-owned, and $21.35 \%$ have the CEO also serving as the chairman of the board.

In order to investigate the impact of corporate social responsibility on the enterprise value, this paper groups samples according to the average of corporate social responsibility score, and conducts descriptive statistical analysis on relevant variables, as shown in Table 3. From Table 3, the corporate value and internal control of companies with good corporate social responsibility performance are significantly higher than those with poor corporate social responsibility performance. The average value of the corporate value of companies with 
good corporate social responsibility performance is 4.874 , while the average value of the corporate value of companies with poor corporate social responsibility performance is 0.453 . There is no significant difference in company size, and the financial risk of companies with good corporate social responsibility performance is lower than that of companies with poor corporate social responsibility performance. In addition, the growth of companies with good corporate social responsibility performance is also higher than that of companies with poor corporate social responsibility performance.

Table 2. Summary of descriptive statistics.

\begin{tabular}{cccccc}
\hline Variable & Observations & Average & SD & Max. & Min. \\
\hline EVA & 7572 & 1.784 & 10.231 & 73.235 & -20.316 \\
CSR & 7572 & 28.460 & 18.781 & 77.860 & -2.44 \\
IC & 7572 & 667.362 & 74.080 & 985.600 & 16.75 \\
Size & 7572 & 22.481 & 1.304 & 26.426 & 20.098 \\
Soe & 7572 & 0.498 & 0.500 & 1 & 0 \\
Con & 7572 & 0.355 & 0.152 & 0.751 & 0.084 \\
Board & 7572 & 2.166 & 0.198 & 2.708 & 1.609 \\
DD & 7572 & 0.372 & 0.053 & 0.571 & 0.333 \\
Risk & 7572 & 1.449 & 1.328 & 9.944 & -0.894 \\
Growth & 7572 & 0.158 & 0.396 & 1.346 & -0.493 \\
Dual & 7572 & 0.214 & 0.410 & 1 & 0 \\
\hline
\end{tabular}

Note: in order to better describe the basic situation of variables, IC refers to the original data before taking logarithm, the same as below.

Table 3. Grouping descriptive statistics.

\begin{tabular}{ccccccc}
\hline \multirow{2}{*}{ Variable } & \multicolumn{2}{c}{ Good Corporate Social } & \multicolumn{3}{c}{ Poor Corporate Social } \\
& \multicolumn{2}{c}{ Responsibility Performance } & \multicolumn{2}{c}{ Responsibility Performance } \\
\cline { 2 - 6 } & Observations & Average & Mean & Observations & Average & Mean \\
\hline EVA & 2280 & 4.874 & 1.061 & 5292 & 0.453 & -0.216 \\
CSR & 2280 & 51.494 & 56.766 & 5292 & 18.537 & 19.665 \\
IC & 2280 & 692.721 & 693.32 & 5292 & 656.438 & 664.305 \\
Size & 2280 & 23.019 & 22.888 & 5292 & 22.250 & 22.080 \\
Soe & 2280 & 0.575 & 1 & 5292 & 0.464 & 0 \\
Con & 2280 & 0.391 & 0.394 & 5292 & 0.340 & 0.320 \\
Board & 2280 & 2.194 & 2.197 & 5292 & 2.154 & 2.197 \\
DD & 2280 & 0.374 & 0.333 & 5292 & 0.372 & 0.333 \\
Risk & 2280 & 1.280 & 1.062 & 5292 & 1.522 & 1.118 \\
Growth & 2280 & 0.168 & 0.104 & 5292 & 0.154 & 0.0817 \\
Dual & 2280 & 0.179 & 0 & 5292 & 0.228 & 0 \\
\hline
\end{tabular}




\subsection{Correlation Coefficient Analysis}

Table 4 is the Person correlation coefficient matrix of the main variables. From the table, the correlation coefficient between enterprise value (EVA) and corporate social responsibility (CSR) is 0.21 , which is significant at the $1 \%$ level. It preliminarily indicates that enterprises undertaking corporate social responsibility can enhance enterprise value. The correlation coefficient between corporate social responsibility (CSR) and internal control (IC) is 0.29 , which is significant at the $1 \%$ level. It preliminarily indicates that the company undertaking corporate social responsibility has more perfect internal control. In addition, the maximum value of variance inflation factor (VIF) of each variable is less than 2 , and the Mean VIF is 1.22 , so it can be considered that there is no serious multi-collinearity.

\subsection{Regression Analysis}

In this paper, the fixed effect model is adopted for empirical analysis, and Table 5 shows the results of model regression. From Table 5, each model is significant at the $1 \%$ level, indicating that the overall regression effect of the model is effective.

In model 1, the coefficient of corporate social responsibility is 1.091 , which is significant at the $1 \%$ level, indicating that corporate social responsibility will enhance corporate value. Hypothesis 1 is verified and a condition for the existence of intermediary effect is established.

In model 2, the coefficient of corporate social responsibility is 0.191 , which is significant at the $1 \%$ level, indicating that there is a significant positive correlation between corporate social responsibility and internal control. Enterprises undertaking corporate social responsibility will promote the improvement of enterprise internal control. Hypothesis 2 is verified, and the second premise of the existence of mediating effect is satisfied.

Table 4. Correlation analysis of the variables.

\begin{tabular}{cccccccccccc}
\hline Variable & 1 & 2 & 3 & 4 & 5 & 6 & 7 & 8 & 9 & 10 & 11 \\
\hline EVA & 1 & & & & & & & & & \\
CSR & $0.21^{* * *}$ & 1 & & & & & & & & \\
IC & $0.29^{* * *}$ & $0.30^{* *}$ & 1 & & & & & & & & \\
Size & $0.35^{* * *}$ & $0.28^{* *}$ & $0.25^{*}$ & 1 & & & & & & & \\
Soe & $0.08^{* * *}$ & $0.11^{* *}$ & $0.07^{* *}$ & $0.31^{* *}$ & 1 & & & & & & \\
Con & $0.14^{* * *}$ & $0.13^{* *}$ & $0.13^{*}$ & $0.26^{* *}$ & $0.24^{* * *}$ & 1 & & & & & \\
Board & $0.04^{* * *}$ & $0.11^{* *}$ & $0.07^{*}$ & $0.24^{* *}$ & $0.23^{* * *}$ & 0.01 & 1 & & & & \\
DD & $0.08^{* * *}$ & 0.13 & 0.01 & $0.08^{* *}$ & $-0.03^{* *}$ & $0.05^{* *}$ & $-0.47^{*}$ & 1 & & & \\
Risk & $-0.09^{* *}$ & $-0.10^{*}$ & $-0.04^{*}$ & $0.11^{* *}$ & $0.09^{* * *}$ & $-0.03^{*}$ & $0.06^{* *}$ & -0.31 & 1 & & \\
Growth & $0.04^{* * *}$ & $0.04^{*}$ & $0.17^{*}$ & $0.04^{* *}$ & $-0.11^{* *}$ & -0.01 & $-0.03^{*}$ & -0.24 & $-0.4^{*}$ & 1 & \\
Dual & $-0.02^{* *}$ & $-0.05^{*}$ & -0.04 & $-0.01^{*}$ & $-0.29^{* *}$ & $-0.10^{*}$ & $-0.18^{*}$ & $0.10^{* * *}$ & -0.04 & $0.03^{*}$ & 1 \\
\hline
\end{tabular}

Note: This table presents Pearson correlation coefficients between the variables. ${ }^{*}$ Statistical significance at the $10 \%$ level. ${ }^{* *}$ Statistical significance at the $5 \%$ level. ${ }^{* *}$ Statistical significance at the $1 \%$ level. 
Table 5. Regression results analysis.

\begin{tabular}{|c|c|c|c|}
\hline \multirow{3}{*}{ Variable } & Model 1 & Model 2 & Model 3 \\
\hline & Coefficient & Coefficient & Coefficient \\
\hline & (T value) & (T value) & (T value) \\
\hline \multirow{2}{*}{ CSR } & $1.091^{\star * *}$ & $0.191^{\star * *}$ & $0.648^{* * *}$ \\
\hline & $(7.96)$ & (15.54) & $(4.76)$ \\
\hline \multirow{2}{*}{ IC } & & & $2.324^{\star * *}$ \\
\hline & & & $(12.90)$ \\
\hline \multirow{2}{*}{ Size } & $2.611^{* * *}$ & $0.176^{\star * *}$ & $2.203^{\star * *}$ \\
\hline & (12.69) & (15.44) & (11.56) \\
\hline \multirow{2}{*}{ Soe } & $-0.317^{\star}$ & -0.017 & $-0.277^{\star}$ \\
\hline & $(-1.82)$ & $(-0.75)$ & $(-1.64)$ \\
\hline \multirow{2}{*}{ Con } & $2.730^{\star * *}$ & $0.212^{* * *}$ & $2.238^{\star * *}$ \\
\hline & $(3.08)$ & $(2.88)$ & $(2.60)$ \\
\hline \multirow{2}{*}{ Board } & -0.774 & -0.066 & -0.620 \\
\hline & $(-0.97)$ & $(-0.96)$ & $(-0.81)$ \\
\hline \multirow{2}{*}{$\mathrm{DD}$} & $8.286^{* * *}$ & -0.142 & $8.616^{* * *}$ \\
\hline & $(2.73)$ & $(-0.54)$ & $(2.95)$ \\
\hline \multirow{2}{*}{ Risk } & $-0.857^{\star * *}$ & $-0.031^{\star * *}$ & $-0.785^{\star * *}$ \\
\hline & $(-11.29)$ & $(-3.32)$ & $(-10.53)$ \\
\hline \multirow{2}{*}{ Growth } & $0.408^{*}$ & $0.370^{* * *}$ & $-0.453^{* *}$ \\
\hline & $(1.85)$ & (12.63) & $(-1.98)$ \\
\hline \multirow{2}{*}{ Dual } & $0.405^{*}$ & -0.020 & $0.451^{\star}$ \\
\hline & $(1.66)$ & $(-0.73)$ & $(1.90)$ \\
\hline \multirow{2}{*}{ Constant } & $-58.370^{* * *}$ & $-3.418^{* * *}$ & $-50.426^{* * 8}$ \\
\hline & $(-11.68)$ & $(-12.25)$ & $(-10.71)$ \\
\hline Year & Yes & Yes & Yes \\
\hline Observations & 7572 & 7572 & 7572 \\
\hline F Value & $34.72^{* * *}$ & $88.51^{\star * *}$ & $37.02^{\star * *}$ \\
\hline $\mathrm{R}^{2}$ & 0.158 & 0.179 & 0.200 \\
\hline
\end{tabular}

Meanwhile, in model 3, the regression coefficient of internal control is 2.324, which is significant at $1 \%$ level and meets the last condition of internal control as a mediator variable. The regression coefficient of corporate social responsibility is 0.648 , which is significantly lower than the regression coefficient of model 1 at the $1 \%$ significance level. Hypothesis 3 is verified. It shows that the internal control in the corporate social responsibility in the process of enterprise value of the 
partial intermediary effect, namely corporate social responsibility can enhance the value of the enterprise by perfecting the internal control. This suggests that corporate socially responsible companies are more likely to establish internal control system, the internal control system as the guarantee of the corporate social responsibility behavior, in order to enhance sustainability of the corporate social responsibility behavior and credibility.

Table 6 shows the regression results of corporate social responsibility, internal control and enterprise value under different property rights. From Table 6, in the model 1 , the state coefficient of corporate social responsibility is greater than the private group, suggesting that state-owned enterprises to fulfill social responsibility to the positive role of enterprise value is bigger. This is because the object of corporate social responsibility proposed by China at the first time is state-owned enterprises. State-owned enterprises are facing more pressure from government departments and are the backbone of the national economy. Therefore, state-owned enterprises have sufficient motivation and obligation to undertake corporate social responsibility. In the results of model 2, the impact of corporate social responsibility fulfillment by state-owned enterprises on internal control is higher than that of non-state-owned enterprises, indicating that state-owned enterprises undertaking corporate social responsibility has a better effect on the improvement of internal control level. In both types of enterprises, the mediating effect of internal control exists and is very significant. We can use the $\beta_{1} \times \gamma_{2} /\left(\beta_{1} \times \gamma_{2}+\gamma_{1}\right)$ to calculate the size of the mediating effect. State-owned group of intermediary effect is 0.506 , and the mediation effect of private groups is 0.195 . That shows the intermediary effect of state-owned enterprises is more obvious. That is to say, compared to the private enterprises, state-owned enterprises through the corporate social responsibility to strengthen internal control, to enhance the effect of enterprise value is bigger, so the mediation effect of internal control is bigger.

\subsection{Caution Test}

In order to enhance the reliability of the research conclusions, the following robustness test was conducted in this paper:

1) Redefining enterprise value, corporate social responsibility index and internal control index. Since the application of EVA is still relatively rare at present and is more widely used in state-owned enterprises, this paper uses Tobin's $Q$ value instead of EVA as the measurement index of enterprise value. As CSR score may be affected by industry factors and varies in different years, this paper makes adjustments to the continuous variable of CSR based on the median of the year and industry. If the score is greater than or equal to the median, take 1 ; if it is less than the median, take 0 . At the same time, this paper also made corresponding adjustments to internal control according to the annual and industry median. If the score is greater than or equal to the median, take 1 ; if it is less than the median, take 0 . The above tests are performed using the adjusted 
results, as shown in Table 7. It can be seen from Table 7 that the CSR coefficients of model 1, model 2 and model 3 are all significant, and the IC coefficient in model 3 is also significant, and the CSR coefficient of model 3 is less than the CSR coefficient of model $1(1.920<2.180)$, which indicates that the internal control has some mediating effect in the process of corporate social responsibility affecting enterprise value.

Table 6. Regression results based on different property rights.

\begin{tabular}{|c|c|c|c|c|c|c|}
\hline \multirow{4}{*}{ Variable } & \multicolumn{3}{|c|}{ State-Owned } & \multicolumn{3}{|c|}{ Private } \\
\hline & Model 1 & Model 2 & Model 3 & Model 1 & Model 2 & Model 3 \\
\hline & Coefficient & Coefficient & Coefficient & Coefficient & Coefficient & Coefficient \\
\hline & (T value) & (T value) & (T value) & (T value) & (T value) & (T value) \\
\hline \multirow{2}{*}{ CSR } & $1.152^{* * *}$ & $0.291^{\star * *}$ & $0.568^{\star * *}$ & $1.081^{\star * *}$ & $0.217^{\star \star \star}$ & $0.871^{\star * \star}$ \\
\hline & $(5.25)$ & (11.73) & $(2.61)$ & $(10.80)$ & (11.83) & $(8.98)$ \\
\hline \multirow{2}{*}{ IC } & & & $2.001^{\star * *}$ & & & $0.971^{\star * *}$ \\
\hline & & & $(11.02)$ & & & $(11.27)$ \\
\hline \multirow{2}{*}{ Size } & $3.747^{* * *}$ & $0.211^{* * *}$ & $3.103^{* * *}$ & $0.658^{\star * *}$ & $0.098^{* * *}$ & $0.562^{* * *}$ \\
\hline & $(12.21)$ & $(14.64)$ & (10.79) & $(4.86)$ & $(6.02)$ & $(4.27)$ \\
\hline \multirow{2}{*}{ Con } & $3.591^{* *}$ & 0.103 & $3.277^{* *}$ & $1.678^{* * *}$ & $0.356^{* * *}$ & $1.332^{* *}$ \\
\hline & $(2.29)$ & $(0.98)$ & $(2.16)$ & (3.09) & $(3.44)$ & $(2.50)$ \\
\hline \multirow{2}{*}{ Board } & $-2.827^{\star \star}$ & $-0.154^{\star}$ & $-2.356^{\star *}$ & 0.510 & -0.001 & 0.511 \\
\hline & $(-2.20)$ & $(-1.72)$ & $(-1.91)$ & $(0.88)$ & $(-0.01)$ & $(0.91)$ \\
\hline \multirow{2}{*}{$\mathrm{DD}$} & 6.134 & -0.386 & $7.310^{*}$ & $3.450^{*}$ & -0.191 & $3.636^{*}$ \\
\hline & $(1.21)$ & $(-1.10)$ & $(1.51)$ & $(1.49)$ & $(-0.52)$ & $(1.60)$ \\
\hline \multirow{2}{*}{ Risk } & $-1.100^{* * *}$ & $-0.020^{*}$ & $-1.038^{* * *}$ & $-0.363^{* * *}$ & $-0.036^{* *}$ & $-0.328^{\star * *}$ \\
\hline & $(-9.92)$ & $(-1.89)$ & $(-9.53)$ & $(-6.11)$ & $(-2.27)$ & $(-5.62)$ \\
\hline \multirow{2}{*}{ Growth } & $0.621^{*}$ & $0.492^{* * *}$ & $-0.883^{\star *}$ & $0.684^{* * *}$ & $0.345^{* * *}$ & $0.349^{*}$ \\
\hline & $(1.33)$ & (10.10) & $(-1.95)$ & (3.43) & $(8.31)$ & $(1.71)$ \\
\hline \multirow{2}{*}{ Dual } & $1.309^{*}$ & -0.043 & $1.441^{* *}$ & -0.175 & -0.024 & -0.152 \\
\hline & $(1.77)$ & $(-0.80)$ & $(2.02)$ & $(-1.28)$ & $(-0.77)$ & $(-1.13)$ \\
\hline \multirow{2}{*}{ Constant } & $-79.496^{\star * *}$ & $-4.049^{* * *}$ & $-67.143^{\star * *}$ & $-16.684^{* * *}$ & $-1.794^{\star \star \star}$ & $-14.941^{\star * *}$ \\
\hline & $(-11.14)$ & $(-11.93)$ & $(-9.91)$ & $(-4.97)$ & $(-3.98)$ & $(-4.59)$ \\
\hline Year & Yes & Yes & Yes & Yes & Yes & Yes \\
\hline Observations & 3768 & 3768 & 3768 & 3804 & 3804 & 3804 \\
\hline F Value & $24.83^{\star * *}$ & $70.50^{\star * *}$ & $27.26^{\star * *}$ & $21.60^{\star * *}$ & $53.18^{\star * *}$ & $26.64^{\star * *}$ \\
\hline $\mathrm{R}^{2}$ & 0.191 & 0.202 & 0.233 & 0.126 & 0.158 & 0.161 \\
\hline
\end{tabular}


Table 7. Statistical results of caution test.

\begin{tabular}{cccc}
\hline & Model 1 & Model 2 & Model 3 \\
\cline { 2 - 4 } Variable & Coefficient & Coefficient & Coefficient \\
\cline { 2 - 4 } & $($ T value $)$ & $($ T value $)$ & $($ T value $)$ \\
\hline CSR & $2.180^{* * *}$ & $0.108^{* * *}$ & $1.920^{* * *}$ \\
& $(7.44)$ & $(8.54)$ & $(6.57)$ \\
IC & & & $2.398^{* * *}$ \\
Constant & $-59.804^{* * *}$ & $-0.638^{* * *}$ & $(12.60)$ \\
Year & $(-12.06)$ & $(-5.32)$ & $-58.274^{* * *}$ \\
Observations & Yes & Yes & $(-11.90)$ \\
F Value & 7572 & 7572 & Yes \\
R & $30.69^{* * *}$ & $89.19^{* * *}$ & 7572 \\
\hline
\end{tabular}

2) Changing the intermediary inspection method. In this paper, Sobel, Goodman-1 (Aroian) and Goodman-2 statistics are used to test the mediating effect, and the results are shown in Table 8. From Table 8, the regression results of the whole sample, state-owned group and non-state-owned group are all significant. The ratio of intermediary effect to total effect is 0.3921 in the whole sample, 0.4831 in the sample of state-owned enterprises, and 0.2185 in the sample of non-state-owned enterprises. This shows that internal control plays an intermediary role in the process in which corporate social responsibility affects enterprise value. Meanwhile, the intermediary effect is more obvious in state-owned enterprises, that is to say, state-owned enterprises improve internal control and further enhance enterprise value by assuming corporate social responsibility. The results of the caution test are consistent with the above, indicating the robustness of the research conclusions obtained in this paper.

\section{Conclusions and Suggestions}

\subsection{Conclusions}

This paper uses the data of listed companies in China to study the relationship among corporate social responsibility, enterprise value and internal control, and draws the following conclusion: 1) corporate social responsibility has a significant positive effect on enterprise value. The higher the level of corporate social responsibility, the greater the enterprise value; 2 ) corporate social responsibility has a significant positive effect on internal control, that is, the performance of corporate social responsibility is conducive to the improvement of internal control; 3) internal control plays an intermediary role in the process in which corporate social responsibility affects enterprise value. That is to say, there are two ways for corporate social responsibility to affect enterprise value. On the one 
Table 8. Sobel-mediating effect test.

\begin{tabular}{cccc}
\hline & Whole Sample & State-Owned & Private \\
\hline Sodiating Effect (Internal Control) & $0.829^{* * *}$ & $1.236^{* * *}$ & $0.281^{\star * *}$ \\
Goodman-1 (Aroian) Test & $(17.98)$ & $(14.03)$ & $(10.44)$ \\
Goodman-2 Test & $(17.97)$ & $(14.02)$ & $(10.43)$ \\
& $(17.99)$ & $(14.04)$ & $(10.45)$ \\
Direct Effects (Social Responsibility) & $1.285^{* * *}$ & $1.322^{* * *}$ & $1.005^{* * *}$ \\
Total Effect & $(11.07)$ & $(6.54)$ & $(12.60)$ \\
& $2.114^{* * *}$ & $2.558^{* * *}$ & $1.286^{* * *}$ \\
The Ratio of Mediating Effects to Total Effects & $(18.37)$ & $(12.63)$ & $(16.37)$ \\
\hline
\end{tabular}

hand, it can enhance enterprise competitiveness through good reputation; on the other hand, it can improve enterprise value through improving internal control. After grouping according to the property right nature of enterprises, it is found that the effect of corporate social responsibility on the value of enterprises in state-owned enterprises is more obvious by improving internal control, which to some extent indicates that the improvement of enterprise value of state-owned enterprises is easier to be achieved by assuming social responsibility.

The contributions of this paper are as follows: 1) it increases the research on the corporate social responsibility, expands the research scope of corporate social responsibility and enriches the existing research results; 2) it takes corporate social responsibility as a kind of enterprise behavior and internal control level as the internal environment of the enterprise. It has great help to analyze the influence of the two on the enterprise value, and deepen managers' understanding of the role of internal control; 3 ) it provides a reference for investors to evaluate enterprises and help investors to make investment decisions. Because the corporate social responsibility behavior can be used as a basis for whether an enterprise has investment prospects, while internal control provides a guarantee for the social responsibility behavior of enterprises, and investors can make investment decisions accordingly.

However, this paper still has some limitations. First, there may be insufficient in the balance of social responsibility index. The corporate social responsibility score published by HeXun is only based on the corporate social responsibility report disclosed by listed companies, but the rating agency does not evaluate the actual corporate social responsibility activities of listed companies. In the future, it is necessary to use more suitable measurement method for empirical research. Secondly, the sample selected in this paper accounts for a relatively low proportion of the whole listed company, so the research sample should be expanded to all listed companies in the future. Finally, there are many ways for corporate social responsibility to affect corporate value. This paper only studies internal control, so it is necessary to further study the mechanism between social responsi- 
bility and corporate value, and investigate more external factors that affect this relationship.

\subsection{Suggestions}

Based on the above research conclusion, this paper puts forward the following Suggestions:

For the enterprise managers, first of all, changing the traditional view of corporate social responsibility. Corporate social responsibility behavior will produce a certain amount of cost, but the economic benefits of it are higher than its cost. It means that corporate social responsibility will not reduce the value of the company, on the contrary, will maximize the value of the enterprise. Therefore, enterprises should actively undertake corporate social responsibilities. Only in this way can the long-term maximization of enterprise value be realized. Second, strengthening the understanding of internal control. The economic role of internal control has beyond the scope of the COSO proposed. It not only can improve the company's internal management, but also a guarantee for enterprises to show their corporate social responsibility behavior to stakeholders. While undertaking corporate social responsibilities, enterprises should improve their internal control. The combination of the two can give full play to the "halo effect" of corporate social responsibility, which is conducive to the realization of their business objectives, and promote the sustainable development of enterprises.

For investors, the corporate social responsibility behavior can be used as a reference to judge the enterprise value. Companies with a sense of corporate social responsibility also have a more complete internal corporate governance system, and the more high-quality financial reports they can provide, the more responsible they are to investors.

For regulators, the implementation environment of corporate social responsibility should be improved. From the current performance of corporate social responsibility in China, government departments should actively assume the responsibility of guiding enterprises and urge enterprises to deepen their awareness of corporate social responsibility. The low enthusiasm of enterprises to fulfill corporate social responsibility mainly increases the cost of enterprises in the short term. From this point of view, the government can give enterprises that actively fulfill corporate social responsibility a certain incentive, such as tax incentives, priority in government procurement, etc. At the same time, a blacklist will be set up to punish enterprises unwilling to fulfill their corporate social responsibilities. Incentive and punishment should be combined to force enterprises to fulfill their corporate social responsibilities, so as to deepen the concept of corporate social responsibility and transform it into spontaneous behavior.

\section{Conflicts of Interest}

The author declares no conflicts of interest regarding the publication of this paper. 


\section{References}

[1] Shen, H.T. (2005) A Study on the Relationship between Corporate Social Responsibility and Corporate Financial Performance-Under the Framework of Stakeholder Theory. Xiamen University, Xiamen.

[2] Kim, Y. and Statman, M. (2012) Do Corporations Invest Enough in Environmental Responsibility? Journal of Business Ethics, 105, 115-129.

https://doi.org/10.1007/s10551-011-0954-2

[3] Gregory, A. and Whittaker, J. (2013) Exploring the Valuation of Corporate Social Responsibility-A Comparison of Research Methods. Journal of Business Ethics, 116, 1-20. https://doi.org/10.1007/s10551-012-1465-5

[4] McGuire, J.B., Sundgren, A. and Schneeweis, T. (1988) Corporate Social Responsibility and Firm Financial Performance. The Academy of Management Journal, 31, 854-872. https://doi.org/10.2307/256342

[5] Jo, H. and Harjoto, M.A. (2012) The Causal Effect of Corporate Governance on Corporate Social Responsibility. Journal of Business Ethics, No. 4, 454-460. https://doi.org/10.1007/s10551-011-1052-1

[6] Ioannou, I. and Serafeim, G. (2015) The Impact of Corporate Social Responsibility on Investment Recommendation: Analysts' Perceptions and Shifting Institutional Logics. Strategic Management Journal, 36, 1053-1081.

https://doi.org/10.1002/smj.2268

[7] El Ghoul, S., Guedhami, O., Kwok, C.C.Y. and Mishra, D. (2011) Does Corporate Social Responsibility Affect the Cost of Capital? Journal of Banking \& Finance, 35, 2388-2408. https://doi.org/10.1016/j.jbankfin.2011.02.007

[8] Wang, Q.G. and Xu, X.Y. (2016) Research on the Value-Creation Mechanism of Corporate Social Responsibility and Its Empirical Test Based on the Stakeholder Theory and Life Cycle Stage Theory. China Soft Science, No. 2, 179-192.

[9] Barnea, A. and Rubin, A. (2010) Corporate Social Responsibility as a Conflict between Shareholders. Journal of Business Ethics, 97, 71-86. https://doi.org/10.1007/s10551-010-0496-Z

[10] Li, Z. (2006) A Study on Relation of Corporate Social Responsibility and Corporate Value: Empirical Evidence from Shanghai Securities Exchange. China Industrial Economy, No. 2, 77-83.

[11] Yang, W.S. and Yang, S.L. (2016) An Empirical Study on the Relationship between Corporate Social Responsibility and Financial Performance under the Chinese Context-Based on the Contrastive Analysis of Large, Small and Medium-Size Listed Companies. Chinese Journal of Management Science, No. 1, 143-150.

[12] Edward, N. and Elizabeth, W. (2009) Corporate Social Responsibility and Financial Performance: The "Virtuous Circle" Revisited. Review of Quantitative Finance and Accounting, 32, 197-209. https://doi.org/10.1007/s11156-008-0090-y

[13] Quan, X.F., Wu, S.N. and Yin, H.Y. (2015) Corporate Social Responsibility and Stock Price Crash Risk: Self-Interest Tool or Value Strategy? Economic Research Journal, No. 11, 49-64.

[14] Lu, D.F. (2002) Economics and Legal Analysis of Corporate Social Responsibility. Law Press, Beijing.

[15] Song, J.B. and Li, A.H. (2010) Study on Corporate Governance Factors of Corporate Social Responsibility. Research on Financial and Economic Issues, No. 5, 23-29.

[16] Yang, S.X., Li, X. and Qiu, G.H. (2007) Research on the Recognition of Internal Control in Chinese Society. Accounting Research, No. 8, 60-67. 
[17] Li, Z.B. (2014) Internal Control, Nature of Actual Controller and Corporate Social Responsibility-Empirical Evidence from Chinese Listed Companies. Economic Survey, 31, 109-114.

[18] Li, Z.B. and Zhang, T.F. (2017) Internal Control, Nature of Property Right and Social Responsibility Information Disclosure: Evidence from Chinese Listed Companies. Accounting Research, No. 10, 86-92.

[19] Kim, Y., Kim, Y. and Kim, H. (2017) Corporate Social Responsibility and Internal Control Effectiveness. Asia-Pacific Journal of Financial Studies, 46, 341-372. https://doi.org/10.1111/ajfs.12172

[20] Hao, D.Y., Qi, G.Y. and Wang, J. (2018) Corporate Social Responsibility, Internal Controls, and Stock Price Crash Risk: The Chinese Stock Market. Sustainability, 10, 1675-1697. https://doi.org/10.3390/su10051675

[21] Gras-Gil, E., Manzano, M.P. and Fernandez, J.H. (2016) Investigating the Relationship between Corporate Social Responsibility and Earnings Management: Evidence from Spain. Business Research Quarterly, 19, 289-299. https://doi.org/10.1016/j.brq.2016.02.002

[22] Orlitzk, M. and Benjamin, J.D. (2001) Corporate Social Performance and Firm Risk: A Meta-Analytic Review. Business and Society, 40, 369-396. https://doi.org/10.1177/000765030104000402

[23] Li, W. and Teng, Y. (2015) Research on the Relationship between Corporate Social Responsibility and Internal Control Effectiveness. Research on Financial and Economic Issues, No. 8, 105-109.

[24] Zhang, C., Shen, H.B. and Gao, X.Z. (2009) Internal Control, CPA Evaluation and Performance Consequence. Auditing Research, No. 6, 79-86.

[25] Kim, J., Song, B.Y. and Zhang, L. (2011) Internal Control Weakness and Bank Loan Contracting: Evidence from SOX Section 404 Disclosures. The Accounting Review, 86, 1157-1188. https://doi.org/10.2308/accr-10036

[26] Prawitt, D.F., Smith, J.L. and Wood, D.A. (2008) Internal Audit Quality and Earnings Management. Accounting Review, 84, 1255-1280. https://doi.org/10.2308/accr.2009.84.4.1255

[27] Beneish, M.D., Billings, M.B. and Hodder, L.D. (2008) Internal Control Weaknesses and Information Uncertainty. The Accounting Review, 83, 665-703. https://doi.org/10.2308/accr.2008.83.3.665

[28] Li, W.F. and Chen, H.L. (2012) Internal Control and Company's Actual Tax Burden. Financial Research, No. 9, 195-206.

[29] Li, W.F., Lin, B. and Lin, D.J. (2012) Can Internal Effectively Avoid Financial Distress? Journal of Finance and Economics, 38, 124-134.

[30] Doyle, J.T., Ge, W. and Mc Vay, S. (2007) Determinants of Weaknesses in Internal Control over Financial Reporting. Journal of Accounting and Economics, 44, 193-223. https://doi.org/10.1016/j.jacceco.2006.10.003

[31] Fang, H.X. and Jin, Y. (2013) Corporate Governance, Internal Control and Inefficient Investment: Theoretical Analysis and Empirical Evidences. Accounting Research, No. 7, 63-69.

[32] Yang, D.M., Lin, B. and Wang, Y.C. (2009) Internal Control, Audit Quality and Large Shareholder Tunneling. Auditing Research, No. 5, 74-81.

[33] Beng, W.G., Jayanthi, K. and Dan, L. (2013) Auditor Reporting under Section 404: The Association between the Internal Control and Going Concern Audit Opinions. Contemporary Accounting Research, 30, 970-995. 
https://doi.org/10.1111/j.1911-3846.2012.01180.x

[34] Freeman, R.E. and Evan, W. (1990) Corporate Governance: A Stakeholder Interpretation. Journal of Behavioral Economics, 19, 337-359. https://doi.org/10.1016/0090-5720(90)90022-Y

[35] Zhang, Z.G., Liang, Z.G. and Yin, K.G. (2012) Research on Corporate Social Responsibility from the Stakeholders Perspective. China Soft Science, No. 2, 139-146.

[36] Jo, H. and Harjoto, M. (2011) Corporate Governance and Firm Value: The Impact of Corporate Social Responsibility. Journal of Business Ethics, 103, 351-383. https://doi.org/10.1007/s10551-011-0869-y

[37] Zhang, Z.G., Zhai, X.C. and Li, G.Q. (2013) An Empirical Study on the Interactive and Inter-Temporal Influence between Corporate Social Responsibility and Corporate Financial Performance. Accounting Research, 8, 32-39.

[38] Cui, J., Jo, H. and Na, H. (2018) Does Corporate Social Responsibility Affect Information Asymmetry? Journal of Business Ethics, 148, 549-572.

https://doi.org/10.1007/s10551-015-3003-8

[39] Albinger, H.S. and Freeman, S.J. (2000) Corporate Social Performance and Attractiveness as an Employer to Different Job Seeking Populations. Journal of Business Ethics, 28, 243-253. https://doi.org/10.1023/A:1006289817941

[40] Harjoto, M. and Jo, H. (2015) Legal vs. Normative CSR: Differential Impact on Analyst Dispersion, Stock Return Volatility, Cost of Capital, and Firm Value. Journal of Business Ethics, 128, 1-20. https://doi.org/10.1007/s10551-014-2082-2

[41] Tian, L.J. (2012) Social Responsibility, Internal Control and Enterprise Performance-Evidence from Civil Aviation Transportation Industry. The Chinese Certified Public Accountant, No. 12, 48-55.

[42] Kim, Y., Myung, S.P. and Wier, B. (2012) Is Earnings Quality Associated with Corporate Social Responsibility? The Accounting Review, 87, 761-796.

https://doi.org/10.2308/accr-10209

[43] Liu, B. and Lu, J.R. (2018) "Good Citizen" or "Good Actor": A Study on Corporate Social Responsibility Behavior Anomalies-From the Perspective of Corporate Earnings Forecasts. Journal of Finance and Economics, 44, 97-108.

[44] Birkey, R.N., Michelon, G., Patten, D.M. and Sankara, J. (2016) Does CSR Assurance on CSR Reporting Enhance Environmental Reputation? An Examination in the U.S. Context. Accounting Forum, 40, 143-152. https://doi.org/10.1016/j.accfor.2016.07.001

[45] Chi, G.H., Yang, J. and Zhang, B. (2016) Has EVA Assessment Improve Enterprise Independent Innovation Capability? Research on the Perspective of Manager's Risk Characteristics and the Nature of Industry. Journal of Audit and Economic, 31, 55-64.

[46] Wen, Z.L., Zhang, L., Hou, J.T. and Liu, H.Y. (2004) Testing and Application of the Mediating Effects. Acta Psychologica Sinica, 35, 614-620. 